\title{
Sorption Profile of Cd(II) Ions Onto Coconut Husk
}

\author{
Syed Moosa Hasany and Rashid Ahmad* \\ Nuclear Chemistry Division, Pakistan Institute of Nuclear Science \& Technology, \\ P.O. Nilore, Islamabad, Pakistan, <rahmad@pinstech.org.pk>
}

\begin{abstract}
The removal of $\mathrm{Cd}(\mathrm{II})$ ions by coconut (Cocos mucifera) husk has been studied extensively optimising all parameters controlling their accumulation on solid surface. Maximum sorption (84\%) of $\mathrm{Cd}(\mathrm{II})$ ions $\left(2.29 \times 10^{-5} \mathrm{M}\right)$ onto sorbent surface is achieved from deionized water in $20 \mathrm{~min}$. using $100 \mathrm{mg}$ of coconut husk $/ 4.5 \mathrm{~cm}^{3}$. The accumulation of $\mathrm{Cd}(\mathrm{II})$ ions monitored over a $\sim 400$-fold concentration $\left(2.30 \times 10^{-6}-\right.$ $9.18 \times 10^{-4} \mathrm{M}$ ) followed Freundlich and Dubinin-Radushkevich $(D-R)$ isotherms. The Freundlich constants $1 / n=0.92 \pm 0.4$ and $C_{m}=52 \pm 22$ mmole $g^{-1}$ and $D-R$ parameters $\beta=-0.0068 \pm 0,0002 \mathrm{~kJ}^{2}$ mole $^{-2}, X_{m}=$ $35.1 \pm 6.8 \mathrm{mmole}^{-1}$ and $E=8.5 \pm 0.1 \mathrm{k} \mathrm{J} \mathrm{mole}^{-1}$ have been evaluated. The variation of temperature in the range of 278-323 $\mathrm{K}$ under optimized conditions yielded thermodynamic entities $\Delta \mathrm{H}=18.1 \pm 0.6 \mathrm{k} \mathrm{J}$ mole ${ }^{-1}$, $\Delta \mathrm{S}=74 \pm 2 \mathrm{~J} \mathrm{~mole}^{-1} \mathrm{~K}^{-1}$ and $\Delta \mathrm{G}_{298 \mathrm{~K}}=-3.8 \pm 0.04 \mathrm{k} \mathrm{J} \mathrm{mole}^{-1}$. The positive enthalpy and negative free energy reflect the endothermic and spontaneous nature of sorption respectively. Among the ions tested EDTA, borate, oxalate and $\mathrm{Eu}(\mathrm{III})$ increased the sorption, while ascorbate, $\mathrm{Ce}(\mathrm{III})$ and $\mathrm{Sb}(\mathrm{III})$ suppressed the sorption. The investigation regarding selectivity of coconut husk reveals that $\mathrm{Cd}(\mathrm{II})$ ions can be separated from $\mathrm{Zn}(\mathrm{II}), \mathrm{Se}(\mathrm{IV}), \mathrm{Tc}(\mathrm{VII})$ and $\mathrm{I}(\mathrm{I})$. This study indicates the potential of coconut husk for the removal of $\mathrm{Cd}(\mathrm{II})$ ions from aqueous solutions/industrial effluents.
\end{abstract}

\section{INTRODUCTION}

Cadmium is an important element due to its deleterious effects and useful applications. It is used in metal and alloys plating, in electrodeposited coatings, as stabilizer in plastics, pigments and chemicals, storage batteries, semiconductors, fungicides and in nuclear technology $/ 1 /$.

Cadmium enters the human body through ingestion and inhalation and accumulates in kidneys. liver, lungs and pancreas. It is one of the most lethal metals because of its 30 years biological half-life in the kidney. It causes renal dysfunction, hypertension, hepatic injury, lung damage, an adverse effect on the reproductive system and bone defects $/ 2,3 /$. The tolerance limit of cadmium in water is $5 \mu \mathrm{g} \mathrm{L}^{-1}$; therefore, it must be removed from water for drinking purposes $/ 4 /$.

The conventional techniques used for the removal of heavy metals from water are filtration, chemical precipitation, reverse osmosis, solvent extraction and membrane techniques $15 /$. The sorption technique is 
superior to them because of its higher efficiency and simple operation. Several low-cost materials have been explored for the removal of cadmium from water /6-9/, but the most efficient and economic sorbent is still required. This paper reports the results of the sorption of cadmium(II) ions onto coconut husk, which is the continuation of our previous work for the exploitation of cheaper materials for the removal of toxic metal ions from aqueous solutions $/ 9-11 \%$

\section{EXPERIMENTAL}

\section{Radiotracer}

The radiotracer ${ }^{115} \mathrm{Cd}$ was prepared by irradiating specpure cadmium oxide in the $10 \mathrm{MW}$ swimming pool-type research reactor (PARR-1) of this institute for 12 hours at a neutron flux of $5 \times 10^{13} \mathrm{n} . \mathrm{cm}^{-2} \mathrm{~s}^{-1}$. After $48 \mathrm{~h}$ cooling the irradiated metal oxide was dissolved in concentrated nitric acid. In order to remove the acid the sample was diluted with deionized water and heated to dryness; this was repeated thrice. After the removal of acid the tracer was diluted to $10 \mathrm{~cm}^{3}$ with deionized water. The radionuclidic and radiochemical purity was checked on $4 \mathrm{k}$ series of 85 Canberra multichannel analyzer coupled with a $25-\mathrm{cm}^{3}$ Ge (Li) detector and was stored for further use.

\section{Reagents}

The reagents used in the present study were of analar grade. Buffer solutions of $\mathrm{pH} \mathrm{1-10} \mathrm{having} \mathrm{ionic}$ strength of $0.1 \mathrm{M}$ were prepared by mixing an appropriate volume of $0.1 \mathrm{M}$ solutions of $\mathrm{HCl}$ and $\mathrm{KCl}$, $\mathrm{CH}_{3} \mathrm{COOH}$ and $\mathrm{CH}_{3} \mathrm{COONa}$ and $\mathrm{H}_{3} \mathrm{BO}_{3}$ and $\mathrm{NaOH}$ for buffers of 1-3, 4-6 and 7-10 respectively.

\section{Coconut husk}

Coconut husk, which is the by-product of coconut (cocos nucifera), was collected from the local market, washed exhaustively with water and finally with deionized water to remove dirt, sand and clay. After washing, it was dried in an oven overnight at $105^{\circ} \mathrm{C}$, then it was split into threads and barks. The thread-like portion was reheated again overnight at $105^{\circ} \mathrm{C}$. It was ground in a pistil mortar up to 40 -mesh size and collected in a bottle.

\section{Sorption measurements}

Five $\mathrm{cm}^{\prime}$ of an electrolyte of known $\mathrm{pH}$ or acid concentration was taken in a glass culture tube with a polyethylene cap. A known concentration of $\mathrm{Cd}(\mathrm{II})$ tracer was added to it and mixed thoroughly. An aliquot of $0.5 \mathrm{~cm}^{3}$ was taken for gross gamma counts $\left(A_{\circ}\right)$. The remaining solution was shaken with $100 \mathrm{mg}$ of coconut husk for 30 minutes on a Stuart Scientific wrist-action shaker. After shaking, phases were separated 
by centrifugation for 3 minutes. Subsequently, $0.5 \mathrm{~cm}^{3}$ of aliquot was withdrawn for radioassay on a Tennelac gross gamma counter equipped with a $30 \mathrm{~cm}^{3}$ well-type $\mathrm{Na}$ (Ti) crystal.

The sorbed concentration of ${ }^{115} \mathrm{Cd}$ at equilibrium was calculated by the difference in the activity of aliquot drawn before $\left(A_{0}\right)$ and after shaking $\left(A_{e}\right)$. The percentage sorption and distribution coefficient $\left(K_{d}\right)$ were calculated as

$$
\begin{aligned}
& \text { \%Adsorption }=\frac{A_{0}-A_{\odot}}{A_{0}} \times 100 \\
& K_{d}=\frac{\text { amount of metal in husk }}{\text { amount of metal in solution }} \times \frac{\text { volume of solution }(\mathrm{V})}{\text { weight of } \operatorname{dry} \text { husk }(\mathrm{W})}=\left(\mathrm{cm}^{3} / \mathrm{g}\right)
\end{aligned}
$$

The \% sorption and the distribution coefficient can be correlated as

$$
\text { \%Adsorption }=\frac{100 K_{d}}{K_{d}+\frac{V / W}{V}}
$$

All the experiments were performed at least in triplicate at $24 \pm 2^{\circ} \mathrm{C}$ or at temperature specified otherwise. The results are the average of at least triplicate independent measurements and precision in most cases is \pm 2 $\%$. The linear regression and slope analyses for the statistical data were carried out. The correlation coefficients for all the regression analyses were in the range of 0.9675-0.9961.

\section{RESULTS AND DISCUSSION}

The sorption of cadmium(II) ions onto coconut husk was optimized by studying various parameters such as nature of electrolyte, shaking time, amount of sorbent and sorbate concentration, to get maximum sorption. The effect of temperature and foreign ions on the sorption and selectivity of sorbent was also studied.

\section{Effect of Electrolyte}

The composition and nature of electrolyte affect the sorption of metal ions by influencing the surface properties of sorbent and the chemical behaviour of sorbate. Therefore, selection of appropriate electrolyte for the sorption is of prime importance. The sorption of cadmium(II) ions onto coconut husk was investigated in deionized water, $\mathrm{HCl}$ and $\mathrm{HNO}_{3}$ in the concentration range of $0.0001-0.1 \mathrm{M}$ and buffer solutions of $\mathrm{pH}$ 110. The concentration of cadmium, amount of coconut husk and agitation time was chosen arbitrarily as 2.29 $\times 10^{-5} \mathrm{M}, 100 \mathrm{mg}$ and $20 \mathrm{~min}$ respectively. The results are shown in Table 1 and Fig. 1 . It is clear from the results of Table 1 that sorption increased with the decrease in acid concentration in both the mineral acids. The results are in conformity with the sorption of $\mathrm{Cd}(11)$ ions onto rice husk /7/ and Haro river sand /9/. Comparatively the sorption in deionized water is greater. The percent sorption of $\mathrm{Cd}(\mathrm{II})$ ions increased with 
the increase in $\mathrm{pH}$ of buffer solutions up to 7; subsequently it decreased with an increase in $\mathrm{pH}$. The lower sorption at higher acidic concentration and lower $\mathrm{pH}$ values may be due to the competition between the positively charged $\mathrm{Cd}^{1-1}$ ions and $\mathrm{H}^{+}$. The maximum sorption around $\mathrm{pH} 7$ buffer solution may be attributed to the cellulosic part of the coconut husk, where site binding sorption occurs. It might be due to the surface complexation phenomenon, which is facilitated by the dissociation of surface functional groups (- COOH and $-\mathrm{OH}$ ). At higher $\mathrm{pH}$ the lower sorption may be attributed to the above mentioned reason. The findings of our work are in conformity with cadmium sorption onto peanut /6/ and onion /12/ skin, and rice hutsk /7/. The deionized water was selected as an appropriate medium for the sorption of $\mathrm{Cd}(\mathrm{II})$ ions onto coconut husk.

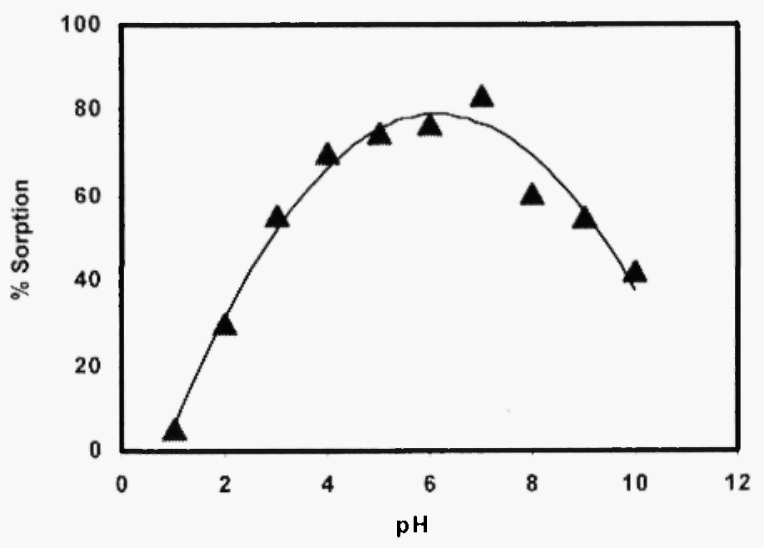

Fig. 1: Effect of $\mathrm{pH}$ on the sorption of $\mathrm{Cd}(\mathrm{II})$ ions $\left(2.29 \times 10^{-5} \mathrm{M}\right)$ onto coconut husk (100 $\left.\mathrm{mg}\right)$

Table 1

Sorption of $\mathrm{Cd}(\mathrm{II})\left(2.29 \times 10^{-5} \mathrm{M}\right)$ ions onto coconut husk (100 mg) after $20 \mathrm{~min}$ agitation time.

\begin{tabular}{|l|c|c|}
\hline Electrolyte & $\mathbf{K}_{\mathbf{d}}\left(\mathbf{c m}^{\mathbf{3}} \mathbf{g}^{\mathbf{1}}\right)$ & \%Sorption \\
\hline Deionized water & 192 & 80.9 \\
\hline $0.1 \mathrm{M} \mathrm{HNO}_{3}$ & 4 & 7.6 \\
\hline $0.01 \mathrm{M} \mathrm{HNO}_{3}$ & 20 & 30.5 \\
\hline $0.001 \mathrm{MHNO}_{3}$ & 69 & 60.4 \\
\hline $0.1 \mathrm{MHCl}$ & 1.5 & 3.2 \\
\hline $0.01 \mathrm{MHCl}$ & 4 & 8.8 \\
\hline $0.001 \mathrm{MHCl}$ & 103 & 69.6 \\
\hline
\end{tabular}

\section{Influence of the amount of sorbent}

The amount of sorbent affects the sorption, therefore, sorption of cadmium $\left(2.29 \times 10^{-3} \mathrm{M}\right)$ ions was investigated as a function of solid/solution ratio in the range of $10-300 \mathrm{mg}$ of coconut husk $/ 4.5 \mathrm{~cm}$ ', using 20 min. shaking time. The results are presented in Fig.2. It is clear from this figure that the \% sorption increased 
up to $100 \mathrm{mg}$ of coconut husk and remained almost constant. Therefore, $100 \mathrm{mg}$ of coconut husk was considered to be an optimum quantity for the removal of cadmium ions from aqueous solution and this amount was used in further experiments.

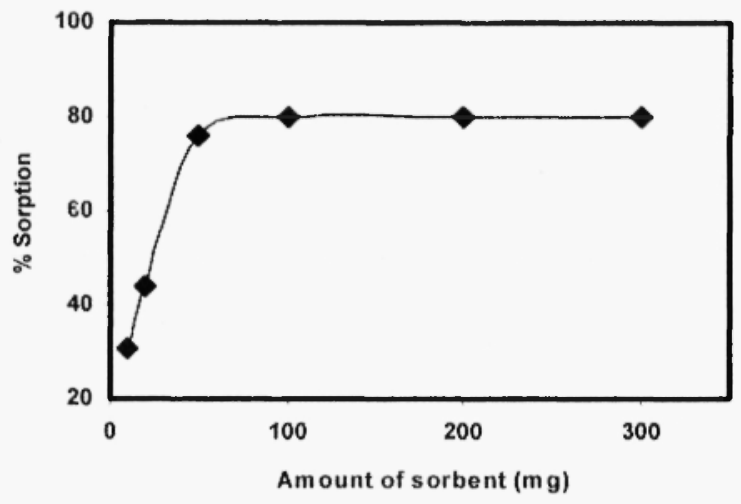

Fig. 2: Influence of the amount of sorbent on the sorption of $\mathrm{Cd}(\mathrm{II})$ ions $\left(2.29 \times 10^{-5} \mathrm{M}\right)$ onto coconut husk.

\section{Effect of shaking time}

For the maximum sorption the effective distribution of sorbate between the sorbent and electrolyte is necessary. The influence of shaking time on the sorption of cadmium(II) ions $\left(2.29 \times 10^{-5} \mathrm{M}\right)$ onto coconut husk has been studied from 1-60 minutes (Fig. 3). It is clear from the figure that sorption increased up to 20 minutes shaking time and beyond 20 minutes no further increase in sorption was observed. For further experiments 20 minutes shaking time was used. The kinetic data of sorption were subjected to the MorrisWeber /13/ equation:

$$
q_{t}=R_{d} \sqrt{t}
$$

where $q_{t}$ is the sorbed amount of $\mathrm{Cd}(\mathrm{II})$ ions onto coconut husk (mole $\mathrm{g}^{-1}$ ) at time interval $t$, and $\mathrm{R}_{\mathrm{d}}$ is the rate of intraparticle diffusion. When $\mathrm{q}_{\mathrm{t}}$ was plotted against $\sqrt{\mathrm{t}}$ a linear plot with a correlation factor of 0.9675 was obtained (Fig. 3). The computed value of intraparticle diffusion rate $R_{d}$ was 6.6 nmole $\mathrm{g}^{-1}$ which is in agreement with 5 nmole $\mathrm{g}^{-1}$ estimated for the sorption of $\mathrm{Hg}(\mathrm{II})$ ions onto coconut husk $/ 5 /$. It is concluded from the value of $R_{d}$ that the sorption is much faster than the surface diffusion and the equilibrium could be established inside the particle.

\section{Influence of the amount of sorbate}

Another important parameter, the initial concentration of $\mathrm{Cd}(\mathrm{II})$ ions, that influences its sorption, has been studied in the range of $2.3 \times 10^{-6}-9.2 \times 10^{-4} \mathrm{M}$, using $20 \mathrm{~min}$ shaking time and $100 \mathrm{mg}$ of coconut husk. The results are presented in Fig. 4 . It is clear that sorption ( $84 \%)$ increased up to $\mathrm{Cd}(\mathrm{II})$ ions concentration of $2.3 \times 10^{-5} \mathrm{M}$ and then decreased with a further increase in the concentration of $\mathrm{Cd}(\mathrm{II})$ ions. The decrease of $\mathrm{Cd}(\mathrm{II})$ ions at its higher concentration may be due to the availability of a lesser number of active sites. 


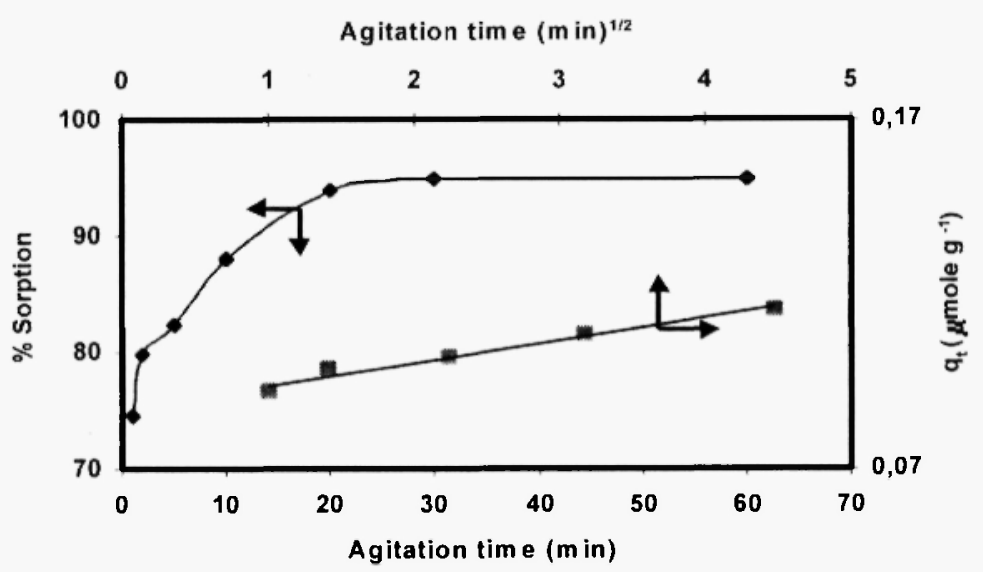

Fig. 3: Sorbed concentration of $\mathrm{Cd}(\mathrm{II})\left(2.29 \times 10^{-5} \mathrm{M}\right)$ onto coconut husk (100 mg) as a function of shaking time.

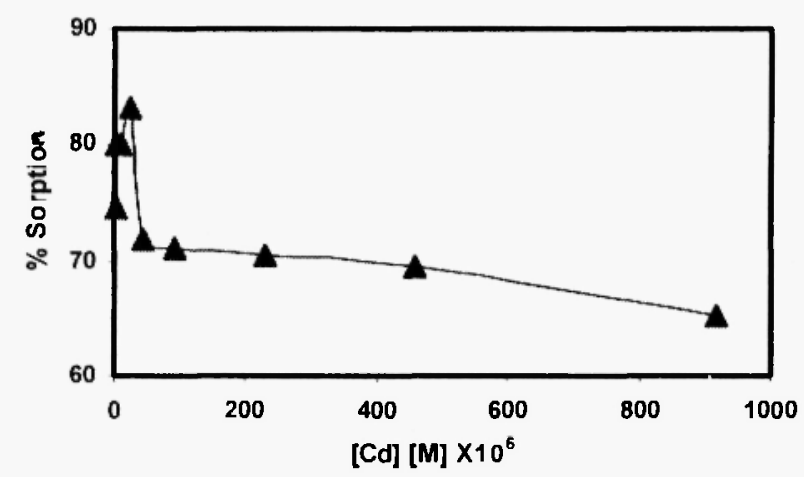

Fig. 4: Effect of concentration of $\mathrm{Cd}(\mathrm{II})$ ions on its sorption onto coconut husk (100 mg).

The sorption data were further analyzed by fitting them to the Freundlich /14/ and Dubinin-Radushkevich (D-R) $/ 15 /$ models. The Freundlich isotherm is the most widely used mathematical description for the sorption of metal ions from solutions. This isotherm suggests that sorption is not restricted to one specific class of sites and assumes surface heterogeneity. It does not predict saturation of the surface of sorbent by sorbate and thus infinite surface coverage is predicted mathematically. The Freundlich isotherm was tested in the following linear form:

$$
\log C_{\text {ads }}=\log C_{m}+\frac{1}{n} C_{e}
$$

where $\mathrm{C}_{\mathrm{ads}}$ and $\mathrm{C}_{\mathrm{e}}$ are the concentration of mercury ions sorbed at equilibrium onto coconut husk (mole $\mathrm{g}^{-1}$ ) and in aqueous solution (mole $\mathrm{L}^{-1}$ ) and $\mathrm{C}_{\mathrm{m}}$ and $1 / \mathrm{n}$ are Freundlich constants. When $\log \mathrm{C}_{\text {ads }}$ was plotted against $\log \mathrm{C}_{\mathrm{e}}$, a linear plot with a correlation factor of 0.9948 was obtained (Fig. 5). The value of Freundlich constant $1 / n=0.92 \pm 0.4$ was computed from the slope of the plot. It indicates the sorption intensity. The fractional value $(0<1 / n<1)$ shows the heterogeneous nature of sorbent surface, the higher the fractional value the higher is the heterogeneity of the surface $/ 16 /$. The $C_{m}=52.6 \pm 22.2 \mathrm{mmole}^{-1}$, the sorption 
capacity, has been computed from the intercept of the linear plot. The values of $1 / n=0.81 \pm 0.05$ and $C_{m}=$ $2.84+0.07$ mmole $^{-1}$ have been reported for $\mathrm{Cd}(\mathrm{II})$ ions sorption onto rice husk $/ 7 /$.

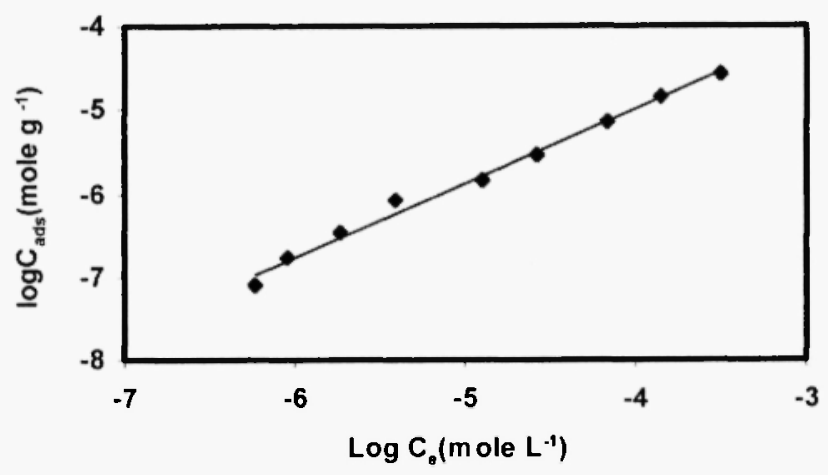

Fig. 5: Freundlich sorption isotherm of $\mathrm{Cd}(\mathrm{II})$ ions onto coconut husk.

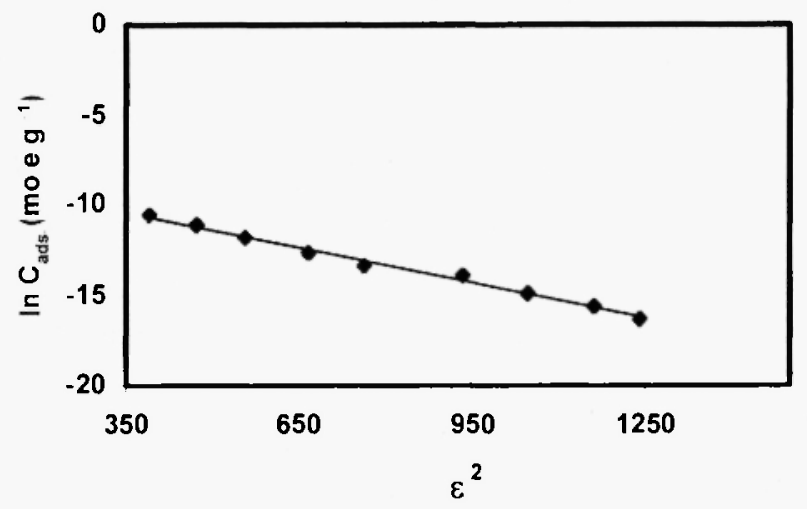

Fig. 6: $\mathrm{D}-\mathrm{R}$ sorption isotherm of $\mathrm{Cd}(\mathrm{II})$ ions onto coconut husk.

The Dubinin-Radushkevich isotherm assumes that there are very small subregions of the sorption surface that are uniform in structure and energetically homogeneous. The linearized form of the $D-R$ isotherm is

$$
\text { In } C_{\text {ads }}=\ln X_{m}-\beta \varepsilon^{2}
$$

where $C_{a d s}$ is the amount of $\mathrm{Cd}(\mathrm{II})$ ions sorbed per unit mass of sorbent (mole $\mathrm{g}^{-1}$ ), $X_{m}$ is the maximum sorption capacity of sorbent $\left(\mathrm{mole}^{-1}\right), \beta$ is a constant $\left(\mathrm{kJ}^{2}\right.$ mole $\left.^{-2}\right)$ and $\varepsilon$ is Polanyi potential which is equal to

$$
\varepsilon=R T \ln \left(1+\frac{1}{C_{e}}\right)
$$

where $\mathrm{R}$ is the universal gas constant in $\mathrm{kJ}$ mole ${ }^{-1}, T$ is the absolute temperature in Kelvin and $\mathrm{C}_{\mathrm{c}}$ is the equilibrium concentration of sorbate in solution (mole $\mathrm{L}^{-1}$ ). The plot $\ln \mathrm{C}_{\mathrm{nds}}$ against $\varepsilon^{2}$ is depicted in Fig. 6 , which is a straight line with a correlation factor of 0.9961 . It can be concluded that $D-R$ isotherm is obeyed 
over the entire range of $\mathrm{Cd}(\mathrm{II})$ ions concentration investigated. The values of $\mathrm{D}-\mathrm{R}$ constants $\beta=-0.0068 \pm$ $0.0002 \mathrm{~kJ}^{2} \mathrm{~mole}^{-2}$ and of $X_{\mathrm{m}}=35.1 \pm 6.8 \mathrm{mmole}^{-1}$ were computed from the slope and intercept of the plot. If the surface of the sorbent is heterogeneous in nature and an approximation to Langmiur isotherm is chosen as a local isotherm for all the sites that are energetically equivalent, then the quantity $\beta$ can be related to the mean sorption energy $(E)$ as

$$
\mathrm{E}=\frac{1}{\sqrt{-2 \beta}}
$$

The value of E calculated from Eq.8, comes out to be $8.5 \pm 0.1 \mathrm{~kJ} \mathrm{~mole}{ }^{-1}$.

\section{Effect of foreign ions on the sorption}

Sorption of $\mathrm{Cd}(\mathrm{II})$ ions onto coconut husk may be influenced by the common anions, cations and complexing agents due to their competition for the sorption sites, association, dissociation and complex formation. The electrical charge on the sorbent surface is also determined by surface coordination with sorbing or other complexing agents. Therefore, the effect of common anions and cations on the sorption of $\mathrm{Cd}(\mathrm{II})$ ions $\left(2.29 \times 10^{-5} \mathrm{M}\right)$ onto coconut husk from deionized water was assessed. The anions were added as their sodium salts and the cations were in the form of nitrates or chlorides. Their concentration was kept at $2.29 \times 10^{-4} \mathrm{M}$, about 10 fold the $\mathrm{Cd}(\mathrm{II})$ ions concentration used in the optimized conditions. The results are presented in Tables 2 and 3. It is clear from the results that the EDTA, borate, oxalate, thiosulphate, carbonate and $\mathrm{Eu}(\mathrm{III})$ enhanced the sorption. Ascorbate, $\mathrm{Sb}(\mathrm{III}), \mathrm{Ce}(\mathrm{III}), \mathrm{Fe}(\mathrm{III}), \mathrm{Pb}(\mathrm{II}), \mathrm{Al}(\mathrm{III}), \mathrm{Cr}(\mathrm{III})$ and $\mathrm{Y}$ (III) suppressed the sorption (69-35\%). In other words the ions which reduced the sorption must be removed from the sorptive medium otherwise sorption of cadmium(II) ions will be drastically curtailed. The reduction in the sorption of $\mathrm{Cd}(\mathrm{II})$ ions onto coconut husk may be due to the formation of strong complexes with ascorbate and their lower sorption affinity towards the sorbent. The effect of metal ions which reduce the sorption of $\mathrm{Cd}(\mathrm{II})$ ions may be due to their competition with these ions for the same sorption sites on the sorbent surface.

\section{Influence of temperature on sorption}

Temperature is one of the major factors that affects the sorption. Therefore, the influence of temperature on the sorption of $\mathrm{Cd}(\mathrm{II})$ ions $\left(2.29 \times 10^{-5} \mathrm{M}\right)$ onto sawdust $(100 \mathrm{mg})$ from deionized water was studied from $278-323 \mathrm{~K}$. It was observed that sorption increased $(-90 \%)$ with an increase in temperature. Similar results have been reported for the sorption of $\mathrm{Cd}(\mathrm{II})$ ions onto rice husk $/ 7 /$ and various oxides surfaces $/ 17,18 /$. The increase in sorption may be due to the acceleration of sorption steps, or may be the creation of some new active sites $/ 19 /$ or maay be due to transport against a concentration gradient, and/or diffusion across the energy barrier $/ 20 /$. 
Table 2

Effect of anions on the sorption of $\mathrm{Cd}(\mathrm{II})\left(2.29 \times 10^{-5} \mathrm{M}\right)$ ions onto coconut husk (100 $\left.\mathrm{mg}\right)$ after $20 \mathrm{~min}$ agitation time from deionized water.

\begin{tabular}{|l|c|c|}
\hline Anions & $\mathbf{K}_{\mathrm{d}}\left(\mathbf{c m}^{\mathbf{3}} \mathbf{g}^{-1}\right)$ & \% Sorption \\
\hline Nil & 224 & 83.2 \\
\hline EDTA & 390 & 89.6 \\
\hline Borate & 296 & 86.8 \\
\hline Oxalate & 280 & 86.2 \\
\hline Thiosulphate & 246 & 84.5 \\
\hline Carbonate & 245 & 84.5 \\
\hline Sulfate & 241 & 84.3 \\
\hline Cyanate & 236 & 83.9 \\
\hline Chloride & 231 & 83.7 \\
\hline Chromate & 221 & 83.1 \\
\hline Tartarate & 202 & 81.7 \\
\hline Citrate & 146 & 76.4 \\
\hline Ascorbate & 25 & 35.5 \\
\hline
\end{tabular}

Table 3

Influence of cations on the sorption of Cd(II) $\left(2.29 \times 10^{-5} \mathrm{M}\right)$ ions onto coconut husk (100 mg) after $20 \mathrm{~min}$ agitation time from deionized water $(\mathrm{b}=$ added as chlorides)

\begin{tabular}{|l|c|c|}
\hline Cations & $\mathbf{K}_{\mathbf{d}}\left(\mathbf{c m}^{3} \mathbf{g}^{-1}\right)$ & \% Sorption \\
\hline $\mathrm{Nil}$ & 224 & 83.2 \\
\hline $\mathrm{Eu}(\mathrm{III})$ & 250 & 84.8 \\
\hline $\mathrm{Mo}^{\mathrm{b}}(\mathrm{V})$ & 166 & 78.6 \\
\hline $\mathrm{K}^{\mathrm{b}}(\mathrm{I})$ & 159 & 77.9 \\
\hline $\mathrm{Ni}(\mathrm{II})$ & 141 & 75.8 \\
\hline $\mathrm{Zr}{ }^{\mathrm{b}}(\mathrm{IV})$ & 132 & 74.6 \\
\hline $\mathrm{Ag}(\mathrm{I})$ & 120 & 72.6 \\
\hline $\mathrm{Co}(\mathrm{II})$ & 116 & 71.9 \\
\hline $\mathrm{Sr}(\mathrm{II})$ & 112 & 71.3 \\
\hline $\mathrm{Y}(\mathrm{III})$ & 104 & 69.8 \\
\hline $\mathrm{Cr}(\mathrm{III})$ & 101 & 69.1 \\
\hline $\mathrm{Al}(\mathrm{III})$ & 99 & 68.7 \\
\hline $\mathrm{Pb}(\mathrm{II})$ & 80 & 63.9 \\
\hline $\mathrm{Fe}(\mathrm{III})$ & 75 & 62.4 \\
\hline $\mathrm{Ce}{ }^{\mathrm{b}}(\mathrm{III})$ & 58 & 56.5 \\
\hline $\mathrm{Sb}{ }^{\mathrm{b}}(\mathrm{III})$ & 25 & 35.6 \\
\hline
\end{tabular}


The $\log K_{c}$ vs $1 / T$ was plotted, where $K_{c}=F /(1-F)$ and $T$ is absolute temperature in Kelvin and $F$ represents the fraction sorbed at equilibrium; a straight line with a correlation factor of 0.9961 was obtained (Fig. 7). The values of $\Delta H, \Delta S$ and $\Delta G$ were computed using the relations:

$$
\begin{aligned}
& \log \mathrm{K}_{\mathrm{e}}=-\frac{\Delta \mathrm{H}}{2.303 \mathrm{RT}}+\frac{\Delta \mathrm{S}}{2.303 \mathrm{R}} \\
& \Delta \mathrm{G}=-\mathrm{RT} \ln \mathrm{K}_{\mathrm{c}}
\end{aligned}
$$

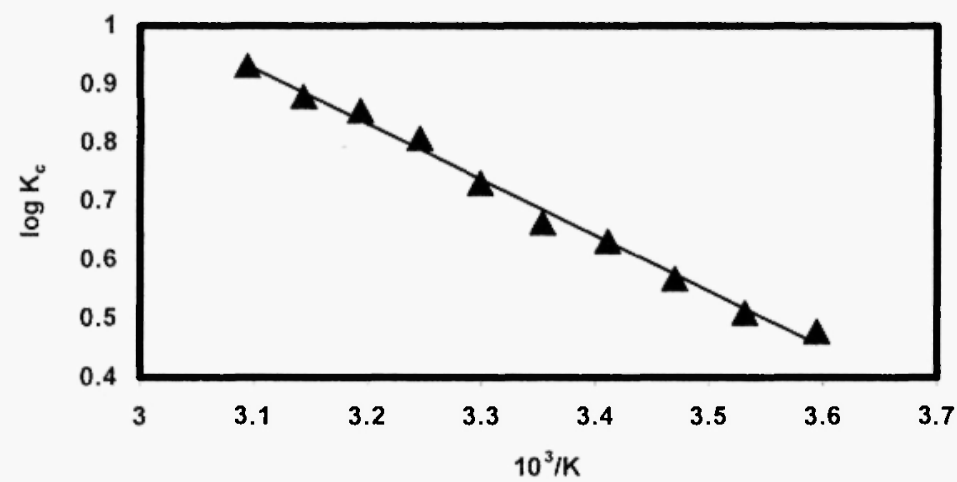

Fig. 7: Variation of sorption equilibrium of $\mathrm{Cd}(\mathrm{II})$ ions onto coconut husk with temperature.

The slope and intercept of Fig. 7 give $\Delta \mathrm{H}=18.1+0.6 \mathrm{~kJ} \mathrm{~mole}^{-1}$ and $\Delta \mathrm{S}=74+2 \mathrm{~J} \mathrm{~mole}^{-1} \mathrm{~K}^{-1}$. The value of $\Delta \mathrm{G}=-3.8+0.04 \mathrm{~kJ} \mathrm{~mole}^{-1}$ at $298 \mathrm{~K}$ was computed using Equation 10 . The values $\Delta \mathrm{H}=0.82 \mathrm{~kJ} \mathrm{~mole}^{-1}, \Delta \mathrm{S}=$ $22.4 \mathrm{~J} \mathrm{~mole}^{-1} \mathrm{~K}^{-1}, \Delta \mathrm{G}=-5.75$ have been reported for $\mathrm{Cd}(\mathrm{II})$ ions sorption onto rice husk $/ 7 /$.

\section{Sorbent selectivity}

In order to check the sorbent selectivity, the sorption onto coconut husk of several radionuclides representing different oxidation states was measured under optimized conditions chosen for $\mathrm{Cd}(\mathrm{II})$ ions. The results along with their separation factors $(\alpha)$ with respect to $\mathrm{Cd}(\mathrm{II})$ ions are presented in Table 4 . All the metal ions studied except $\mathrm{Hg}$ (II), $\mathrm{Cr}$ (III) and $\mathrm{Eu}$ (III) (84-91\%) have lower sorption than $\mathrm{Cd}$ (II) ions. Zn(II), $\mathrm{Se}(\mathrm{IV}), \mathrm{Tc}(\mathrm{VII})$ and $\mathrm{l}(\mathrm{l})$ have shown lower sorption $(<13 \%)$ which indicates that these can be separated from $\mathrm{Cd}(\mathrm{II})$ ions using coconut husk column.

\section{CONCLUSIONS}

1. Up to $90 \% \mathrm{Cd}(\mathrm{II})$ ions can be removed by coconut husk from deionized water in 20 min.

2. The kinetics of sorption of $\mathrm{Cd}(\mathrm{II})$ ions onto coconut husk obey Reichenberg, Morris-Weber and Lagergren equations.

3. The sorption of $\mathrm{Cd}(\mathrm{II})$ ions onto coconut husk follows Freundlich and D-R isotherms. 
Table 4

Sorption of other metals onto coconut husk (100 mg) after $20 \mathrm{~min}$ agitation time from deionized water.

\begin{tabular}{|l|c|c|c|}
\hline Metal ions & $\mathbf{K}_{\mathbf{d}}\left(\mathbf{c m}^{3} \mathbf{g}^{-1}\right)$ & \% Sorption & $\propto=\mathbf{K}_{\mathbf{d}} \mathbf{C d}(\mathbf{I I}) / \mathbf{K}_{\mathbf{d}} \mathbf{M}$ \\
\hline $\mathrm{Cd}(\mathrm{II})$ & 224 & 83.2 & - \\
\hline $\mathrm{Hg}(\mathrm{II})$ & 915 & 90.9 & 0.2 \\
\hline $\mathrm{Cr}(\mathrm{III})$ & 291 & 86.6 & 0.8 \\
\hline $\mathrm{Eu}(\mathrm{III})$ & 239 & 84.1 & 0.9 \\
\hline $\mathrm{Tm}(\mathrm{II})$ & 170 & 79.1 & 1.3 \\
\hline $\mathrm{Ag}(\mathrm{I})$ & 89 & 66.2 & 2.5 \\
\hline $\mathrm{Sb}(\mathrm{III})$ & 59 & 56.5 & 3.8 \\
\hline $\mathrm{Co}(\mathrm{II})$ & 53 & 53.8 & 4.2 \\
\hline $\mathrm{Cs}(\mathrm{I})$ & 14 & 24.1 & 16.0 \\
\hline $\mathrm{I}(\mathrm{I})$ & 6 & 12.2 & 37.3 \\
\hline $\mathrm{Tc}(\mathrm{VII})$ & 2 & 4.6 & 112 \\
\hline $\mathrm{Se}(\mathrm{IV})$ & 1.4 & 2.9 & 160 \\
\hline $\mathrm{Zn}(\mathrm{II})$ & 0 & 0 & $\propto$ \\
\hline
\end{tabular}

4. The positive value of $\Delta \mathrm{H}$ and negative value of $\Delta \mathrm{G}$ show the endothermic and spontaneous nalure of sorption respectively.

5. EDTA, borate, oxalate, thiosulphate, carbonate and Eu(III) have enhanced the sorption while ascorbate and $\mathrm{Sb}(\mathrm{III})$ have reduced it.

6. The coconut husk column can be used to separate $\mathrm{Cd}$ (II) ions from $\mathrm{Zn}$ (II), $\mathrm{Se}(\mathrm{IV}), \mathrm{Tc}(\mathrm{VII})$ and I(1) ions.

\section{REFERENCES}

1. M. Webb. The Chemistry, Biochemistry and Biology of Cadmium, Elsevier, New York, 1979.

2. H.G. Seiler, H. Sigel and A. Sigel. Handbook on Toxicity of Inorganic Compounds, Marcel Dekker, Inc., New York, 1988.

3. E.R. Plunkett, Handbook of Industrial Toxicology, $3^{\text {rld }}$ Ed., Edward Arnold Ltd., Australia, 1987.

4. S.M. Hasany, Nucleus, 37, 187 (2000).

5. M. Streat (Ed.), Ion Exchange for Industry, Ellis Horwood Ltd., Chichester, 1988.

6. J.M. Randall, E. Hautala and G. McDonald, J. Appl. Polym. Sci. 22, 379 (1978).

7. N. Khalid, A. Rahman and S. Ahmad, Radiochim Acta, 83, 157 (1998) and the references therein.

8. M. Yu, W. Tian, O. Sun,W. Shen, G. Wang and N. Xu, Anal. Chim. Acta. 428, 209 (2001).

9. S.M. Hasany and M.H. Chaudhary, J. Radioanal. Nucl. Chem. 247, 335 (2001) and references therein.

10. S.M. Hasany, R. Ahmad and M.H. Chaudhary, Radiochim, Acta, Communicated.

11. S.M. Hasany and R. Ahmad, Main Group Metal Chem., 25, 719 (2002). 
12. P. Kumar and S.S. Dara, J. Polym. Sci., Polym. Chem., 19, 397 (1981).

13. J. Weber and J.C. Morris, J. Saint. Eng. Div. ASEC 899(SA2), 31 (1963).

14. H. Freundlich, Colloid and Capillary Chemistry, Methuen, London, 1926.

15. M.M. Dubinin and L.V. Radushkevich, Proc. Acad. Sci, USSR, Phys. Chem. Soc. 55, 331 (1947).

16. P. Benes and V. Majer, Trace Chemistry of Aqueous Solutions, Elsevier, Amsterdam, 1980.

17. S.P. Mishra and V.K. Singh, Radiochim. Acta 68, 251 (1995).

18. S.P. Mishra and V.K. Singh, Radiochim. Acta 76, 97 (1997).

19. J.W. Hensley, J. Am. Ceramics Soc., 34, 188 (1951).

20. Y.P. Ting and W.K. Teo, Biores. Tech. 50, 113 (1994). 